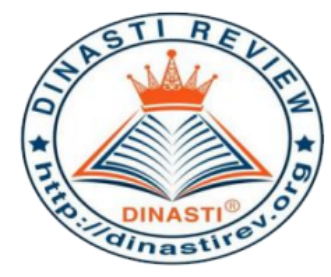

+62 878-9658-6407

087896586407

https://dinastirev.org/JIMT

editor@dinastirev.org (G)

\title{
ANALISIS PERPINDAHAN MEREK (STUDI KASUS PADA PENGGUNA SMARTPHONE OPPO DI CIGANJUR, JAGAKARSA)
}

\section{Endah Mahayu Putri ${ }^{1}$, Miguna Astuti ${ }^{2}$,}

1) Universitas Pembangunan Nasional Veteran Jakarta, Jakarta, Indonesia

2) Universitas Pembangunan Nasional Veteran Jakarta, Jakarta, Indonesia

ARTICLE INFORMATION

Received: 5 April 2020

Revised: 15 April 2020

Issued: 22 April 2020

Corresponding Author: Endah

Mahayu

E-mail:

miguna.astuti@upnvj.ac.id

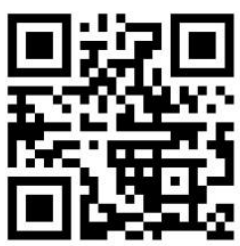

DOI:10.31933/JIMT
Abstrak: Penelitian ini adalah penelitian kuantitatif yang bertujuan untuk mengetahui pengaruh atribut produk, pencarian variasi, dan harga pada pergantian merek. Populasi dalam penelitian ini adalah pengguna smartphone Oppo di Ciganjur, Jagakarsa. Ukuran sampel diambil sebanyak 75 responden, dengan metode non probability sampling dengan metode purposive sampling. Pengumpulan data dilakukan melalui penyebaran kuesioner. Teknik analisis yang digunakan adalah metode analisis PLS (Partial Least Square) dengan perangkat lunak SmartPLS 3.2.7. Hasil penelitian ini menunjukkan bahwa (1) Atribut produk memiliki pengaruh positif dan signifikan terhadap pengalihan merek. (2) pencarian varietas tidak memiliki pengaruh dan tidak signifikan terhadap pengalihan merek (3) Harga memiliki pengaruh positif dan signifikan terhadap pengalihan merek. Dari tiga variabel independen yaitu atribut produk, mencari variasi dan harga yang memberikan kontribusi terbesar adalah variabel atribut produk.

Kata Kunci: Perpindahan Merek; Harga; Atribut Produk; Mencari Variasi

\section{PENDAHULUAN}

Kini smartphone selain sebagai alat komunikasi, smartphone juga bisa dapat memenuhi gaya hidup masyarakat. Banyaknya masyarakat yang menyukai foto . Masuknya perusahaan smartphone dari China yang unggul pada saat ini yaitu smartphone Oppo. Smartphone Oppo merupakan smartphone berbasis android yang unggul dan dapat bersaing dengan kompetitor terkemuka yang lebih dahulu hadir di pasar Indonesia. Smartphone Oppo menawarkan berbagai macam varian warna, fitur yang menarik, berbagai macam tipe Oppo, dan Oppo mampu memanjakan para pengguananya yang menyukai selfie.

Pesatnya perkembangan smartphone Oppo menyebabkan daya tarik dan daya tawar konsumen menjadi lebih tinggi terhadap suatu produk, salah satunya dikawasan Kelurahan Ciganjur yang terdapat banyak gerai-gerai smartphone yang menjual produk smartphone. Pilihan produk yang ditawarkan oleh produsen memberikan kesempatan bagi konsumen untuk melakukan pembelian dengan beralih dari satu merek ke merek lainnya. 
Tabel 1. Top Brand Award Kategori Smartphone 2015-2017

\begin{tabular}{|c|c|c|c|c|c|c|}
\hline \multicolumn{7}{|c|}{ Smartphone } \\
\hline \multirow[b]{2}{*}{ No } & \multicolumn{2}{|c|}{ Tahun 2015} & \multicolumn{2}{|c|}{ Tahun 2016} & \multicolumn{2}{|c|}{ Tahun 2017} \\
\hline & Merek & TBI & Merek & TBI & Merek & TBI \\
\hline 1. & Samsung & $29,7 \%$ & Samsung & $43,4 \%$ & Samsung & $46,4 \%$ \\
\hline 2. & Blackberry & $24,7 \%$ & Nokia & $10,9 \%$ & Nokia & $8,8 \%$ \\
\hline 3. & Nokia & $16,7 \%$ & Blackberry & $9,8 \%$ & Blackberry & $8,0 \%$ \\
\hline 4. & Iphone & $4,5 \%$ & Iphone & $5,8 \%$ & Iphone & $5,1 \%$ \\
\hline 5. & Smartfren & $3,8 \%$ & Smartfren & $5,4 \%$ & Smartfren & $5,1 \%$ \\
\hline 6. & Cross & $3,0 \%$ & Lenovo & $4,0 \%$ & Lenovo & $4,4 \%$ \\
\hline 7. & Advan & $2,9 \%$ & Oppo & $3,4 \%$ & Oppo & $4,1 \%$ \\
\hline 8. & Mito & $2,5 \%$ & Asus & $3,3 \%$ & Asus & $3.8 \%$ \\
\hline 9. & Lenovo & $2,4 \%$ & & & & \\
\hline 10. & Oppo & $2,2 \%$ & & & & \\
\hline
\end{tabular}

Sumber: $\underline{w w w . t o p b r a n d-a w a r d . c o m}$

Pada tahun 2015 smartphone Oppo berada pada peringkat 10 dengan persentase 2,2\%, selanjutnya pada tahun 2016 smartphone Oppo meningkat dengan terjadinya peningkatan peringkat pada posisi 7 dengan persentase 3,4\%, Lalu pada tahun 2017 tetap berada diposisi ke 7 dengan persentase kenaikan $4,1 \%$.

Smartphone Oppo dapat menguasai pasang pasar Indonesia dengan berbagai macam strategi, yaitu smartphone Oppo dapat masuk ke semua segmen pasar, dari yang kelas ekonomi rendah hingga atas pada berbagai tingkat harga yang ditawarkan smartphone Oppo sehingga konsumen dapat memiliki smartphone Oppo.

Tabel 2. Market Share Smartphone 2016-2017

\begin{tabular}{|c|c|c|c|}
\hline \multicolumn{4}{|c|}{$\begin{array}{l}\text { IDC Comparison of Top 5 Smartphone Companies in } \\
\text { Indonesia, 2016 - 2017. By Market Share }\end{array}$} \\
\hline $\begin{array}{l}2016 \text { Top } 5 \text { Smartphone } \\
\text { Companies }\end{array}$ & & $\begin{array}{l}2017 \text { Top } 5 \text { Smartphone } \\
\text { Companie }\end{array}$ & \\
\hline Company & MarketShare & Company & MarketShare \\
\hline 1. Samsung & $28,8 \%$ & 1. Samsung & $31,8 \%$ \\
\hline 2. Oppo & $16,6 \%$ & 2. OPPO & $22,9 \%$ \\
\hline 3. Advan & $10,5 \%$ & 3. Advan & $7,7 \%$ \\
\hline 4. ASUS & $6,8 \%$ & 4. ASUS & $6,5 \%$ \\
\hline 5. Vivo & $5,6 \%$ & 5. Vivo & $6,0 \%$ \\
\hline 6. Others & $31,6 \%$ & 6. Others & $25,1 \%$ \\
\hline $\begin{array}{l}\text { Total Shipment Volumes (in } \\
\text { millions) }\end{array}$ & 30,3 & $\begin{array}{l}\text { Total Shipment } \\
\text { Volumees (in millions) }\end{array}$ & 30,4 \\
\hline
\end{tabular}

Sumber: https://tekno.kompas.com

Bahwa smartphone Oppo berada pada posisi kedua, terjadinya kenaikan pertumbuhan pangsa pasar di Indonesia pada tahun 2016 sebesar 16,6\% dan pada 2017 sebesar 22,9\%. hal tersebut di indikasikan perubahan pangsa pasar smartphone yang disebabkan oleh adanya suatu perubahan permintaan pada konsumen. Terdapat beberapa penelitian bahwa perpindahan merek smartphone dapat dipengaruhi oleh beberapa variabel, antara lain atribut produk, mencari variasi, dan harga. Dalam penelitian Ramadhan \& Suhermin (2016) dan Wibowo, dkk (2014) mengatakan atribut produk berpengaruh signifikan terhadap perpindahan merek. Namun, menurut penelitian Arianto (2013) menyatakan bahwa atribut produk berpengaruh tidak signifikan terhadap perpindahan merek.

Selanjutnya menurut Fitikasri \& Andryan (2018), Faustine (2015), dan Indarwati \& Untarini (2017), Khasanah \& Kuswati (2015), Indarwati \& Untarini (2017) dan Ariani (2014) 
menyatakan variety seeking berpengaruh signifikan terhadap perpindahan merek Sedangkan, menurut Yuliyanto, dkk (2015) bahwa tidak memiliki pengaruh signifian terhadap perpindahan merek.

Menurut Dianti (2016) dan Jayawijaya, dkk (2017) mengatakan bahwa harga berpengaruh positif terhadap perpindah merek. Lain hal nya dengan Arianto (2013) mengatakan bahwa harga memiliki pengaruh tidak signifikan terhadap perpindahan merek.

\section{KAJIAN PUSTAKA \\ Perpindahan Merek}

Menurut Kumar \& Chaarlas dalam Faustine (2015, hlm.144) mengatakan bahwa perpindahan merek adalah proses dimana konsumen beralih dari satu produk ke produk lain, tetapi dari kategori yang sama. Kemudian menurut jenisnya Sutisna dalam Sudaryono (2014, hlm.84) keterlibatan konsumen terbagi mejadi dua macam keterlibatan, yaitu keterlibatan situasional (situational linvolvement) dan keterlibatan tahan lama (enduring involvement). Keterlibatan situasional hanya terjadi seketika pada situasi khusus dan temporer sifatnya. Lalu, menurut Soloman dalam Sudaryono (2014, hlm.85) menyebutkan enduring involvement, artinya tingkat keterlibatan seseorang konsumen terhadap suatu merek produk lebih memperhatikan risiko sosial yang mungkin diterimanya. Kondisi yang mempengaruhi terciptanya enduring involvement adalah pentingnya produk pada citra konsumen, daya tarik emosional dan simbol-simbol dari kelompok rujukan. Sementara kondisi utama terciptanya keterlibatan situasional adalah adanya simbol-simbol nilai-nilai rujukan pada suatu produk, serta adanya risiko pembelian. Keterlibatan situasional yang disebabkan oleh adanya kondisi dan adanya risiko pembelian, karena konsumen merasakan adanya ketidakpastian mengenai keputusannya atau adanya akibat buruk yang potensial dalam pembuatan keputusan. Adapun dimensi dalam perpindahan merek yaitu keterlibatan konsumen, sedangkan indikator dari keterlibatan konsumen yaitu keterlibatan situsional dan keterlibatan tahan lama.

\section{Atribut Produk}

Menurut Tjiptono (2008, hlm.103) mendefinisikan sebagai atribut produk unsur-unsur produk yang dipandang penting oleh konsumen dan dijadikan dasar pengambilan keputusan pembelian. Kemudian, menurut Sutojo (2009, hlm.143) Atribut produk mempunyai pengaruh besar pada persepsi pembeli terhadap produk. Hal itu disebabkan secara fisik atribut produk membawa berbagai manfaat yang dibutuhkan dan diinginkan pembeli. Atribut produk yang paling besar perananya dalam menciptakan persepsi konsumen antara lain:

a. Mutu produk adalah kemampuan produk menunaikan fungsi utamanya. Dengan perkataan lain tingkat mutu produk ditentukan oleh kemampuan memenuhi kebutuhan utama pembeli atau manfaat inti. Tinggi rendahnya mutu produk di mata konsumen antara lain ditentukan oleh (a) Panjang-pendeknya jangka waktu pemakaian produk tanpa gangguan yang berarti, (b) Tinggi rendahnya nilai manfaat yang disajikan produk, (c) cara penggunaan produk yang mudah, dan (d) Biaya reparasi yang tidak memberatkan pemilik produk yang bersangkutan

b. Bentuk dan pernak-pernik produk. Bentuk dan pernak-pernik (accessories) produk merupakan salah satu sarana untuk menangkan persaingan. Dengan bentuk dan pernak-pernik yang berbeda konsumen dapat membedakan produk perusahaan yang satu dengan perusahaan lain. Produsen yang inovatif selalu berusaha menciptakan bentuk dan pernak pernik-pernik produk yang lebih menarik dibandingkan dengan produk saingan mereka. Untuk melakukan hal itu secara 
periodik mereka melakukan riset pemasaran. Mereka mendatangi mereka para pembeli untuk menanyakan kesannya terhadap produk mana yang paling disukai. Pernak-pernik apa yang disarankan respondents untuk ditambahkan atau dikurangkan. Pandapat dan saran respondents tersebut kemudian dianalisis, terutama ditinjau dari pernak-pernik dimata respondents, dan tambahan biaya produksi yang harus ditanggung perusahaan untuk memenuhi saran-saran pembeli tadi. Pernak-pernik yang tinggi nilainya di mata mayoritas respondents perlu dipertimbangkan. Sedangkan saran pernak-pernik yang disarankan sebagian kecil respondents dan hanya akan menambah biaya produksi saja tidak perlu diperhatikan.

c. Desain produk. Tujuan desain produk adalah guna membedakan produk yang dihasilkan perusahaan dengan produk-produk saingan. Produk dengan desain yang canggih dapat menarik minat pembeli. Oleh karena itu desain produk yang menarik pemandangan konsumen dapat berfungsi sebagai salah satu sarana untuk menunjang kemampuan bersaing. Disamping menarik pemandangan desain produk harus dapat membantu meningkatkan nilai penggunaan produk misalnya kemudahan, ketangguhan, dan keamanan penggunaanya serta kemudahan pengepakan dan pengiriman barang.

Berdasarkan teori di atas peneliti membuat konstruk tentang atribut produk yaitu suatu kesatuan atau unsur-unsur produk yang memiliki manfaat pada suatu produk dan dijadikan dasar pengambilan keputusan oleh konsumen. Dimensi dalam atribut produk yaitu mutu produk dan desain produk. Indikator dari atribut produk yaitu panjang-pendeknya jangka waktu pemakaian produk tanpa gangguan yang berarti tahan lama, tinggi rendahnya nilai manfaat yang disajikan produk, cara penggunaan produk yang mudah, dan biaya reparasi. Selanjutnya, indikator bentuk dan pernak pernik produk yaitu estetika dan inovatif. Sedangkan, indikator desain produk yaitu kemudahan, ketangguhan, keamanan, dan pengepakan.

\section{Mencari Variasi}

Menurut Hawkins (2010, hlm. 396) yang mengatakan bahwa mencari variasi adalah komitmen kognitif untuk membeli merek yang berbeda karena faktor-faktor seperti stimulasi yang terlibat dalam mencoba merek yang berbeda, keingintahuan, kebaruan, atau mengatasi kebosanan dengan hal lama yang sama.

Berdasarkan teori di atas maka dapat disimpulkan bahwa mencari variasi (varietyseeking) adalah suatu perilaku konsumen yang ditandai dengan keterlibatan konsumen dalam mencoba merek yang berbeda, keingintahuan, kebaruanan pada suatu produk. Indikator dalam mencari variasi (varietyseeking) yaitu keingintahuan, rasa bosan, dan mengevaluasi produk.

\section{Harga}

Menurut Oentoro (2012, hlm.149) harga adalah suatu nilai tukar yang bisa disamakan dengan uang atau barang lain untuk manfaat yang diperoleh dari suatu barang atau jasa bagi seseorang atau kelompok pada waktu tertentu dan tempat tertentu. Harga memiliki dua peranan utama dalam proses pengambilan keputusan para pembeli, yaitu peranan alokasi dan peranan informasi. Peranan alokasi harga adalah fungsi harga dalam membantu para pembeli untuk memutuskan para pembeli untuk memutuskan cara memperoleh manfaat. Sedangkan peranan informasi harga adalah fungsi harga dalam "mendidik" konsumen mengenai faktor 
produk, misalnya kualitas. Persepsi yang sering berlaku adalah bahwa harga yang mahal mencerminkan kualitas yang tinggi.

Dalam suatu penetapan harga, terdapat tujuan dari penetapan harga yaitu menurut Lovelock, dkk (2010, hlm.159)

a. Menciptakan pendapatan dan laba

Dalam batasan tertentu, perusahaan yang bertujuan mencari laba ingin memaksimalkan pendapatan. Ketika permintaan rendah, organisasi-organisasi tersebut dapat menawarkan diskon khusus untuk bisnis tambahan. Sebaliknya, ketika permintaan melebihi kapasitas, jenis bisnis seperti ini dapat meningkatkan harga dan berfokus pada segmen yang bersedia membayar dengan harga premium.

b. Membangun permintaan dan mengembangkan basis pengguna

Memaksimalkan kelompok konsumen yang menjadi subjek dalam mencapai tingkat keuntungan minimum tertentu, mungkin akan menjadi lebih penting ketimbang memaksimalkan laba. Dalam menciptakan suatu kesan akan peluncuran yang sukses, dan untuk memperkaya citra perusahaan, adalah penting bagi perusahaan untuk dipandang mampu menarik banyak bisnis dari jenis konsumen yang tepat. Diskon harga perkenalan sering kali digunakan untuk merangsang minat konsumen dan memperkenalkan produk, terkadang dikombinasikan bersama kegiatan promosi lain seperti kontes dan pemberian hadiah.

Berdasarkan uraian teori di atas dapat disimpulkan bahwa harga adalah suatu nilai tukar yang disamakan dengan uang untuk memenuhi kebutuhan dan keinginan terhadap barang dan jasa. Dengan indikator antara lain peranan alokasi, peranan informasi dan diskon. Selanjutnya, keterkaitan antara masing-masing variabel bebas terhadap variabel terikat dapat dijelaskan pula melalui beberapa penelitian terdahulu. Menurut hasil penelitian yang dilakukan oleh Ramadhan (2016) atribut produk memiliki pengaruh signifikan terhadap perpindahan merek. Hasil ini menunjukkan bahwa semakin baik atribut produk, maka akan semakin meningkatkan perpindahan merek. Sama halnya menurut hasil penelitian yang dilakukan oleh Wibowo, dkk (2014) yang menyatakan bahwa atribut produk memiliki pengaruh positif dan signifikan terhadap perpindahan merek.

Sedangkan terkait variabel mencari variasi terhadap perpindahan merek. Dalam penelitian Khasanah \& Kuswati (2014) menyatakan bahwa kegiatan mencari vasiasi (varietyseeking) memiliki pengaruh terhadap perpindahan merek. Hal tersebut sejalan dengan hasil penelitian dari Fintikasari \& Ardyan (2018) yang menyatakan bahwa mencari memiliki pengaruh positif dan signifikan. Dimana berbagai pencarian tanda menjadi kunci pemicu utama pada peralihan merek, pilihan terbatas akan membuat konsumen cenderung memilih satu merek atau loyal pada merek tertentu.

Kemudian terkait variabel harga terhadap perpindahan merek. Terdapat penelitian hasil penelitian Dianti (2016) harga dinyatakan pengaruh positif dan signifiakn terhadap perpindahan merek. Sejalan pula dengan Jayawijaya, dkk (2017) yang menunjukkan bahwa manfaat yang diperoleh responden dengan Harga produk. Jika Harga sesuai dengan keinginan Responden terhadap produk, maka ia akan berpindah merek.

\section{METODE PENELITIAN}

Penelitian ini merupakan penelitian penjelasan (explanatory research) yang bertujuan untuk menjelaskan hubungan antara variabel melalui pengujian hipotesis (Tjiptono, 2006:56). Adapun jenis data yang digunakan adalah data kuantitatif, dengan sumber data primer yang diperoleh dari hasil penyebaran kuesioner menggunakan skala likert yang diberikan kepada 
75 warga kelurahan Ciganjur yang sebelumnya menggunakan smartphone merek lain dan berpindah menjadi pengguna smartphone Oppo lain dan alat analisis yang digunakan yaitu SmartPLS.

\section{HASIL DAN PEMBAHASAN}

Berdasarkan pengujian yang dilakukan, diketahui bahwa kuisioner dinyatakan valid dan reliabel, dengan nilai validitas 0,5 dan nilai realibilitas diatas nilai 0,7 . Selanjutnya, diperoleh pula hasil uji $\mathrm{R}^{2}$ dengan nilai $\mathrm{R}^{2}$ adjusted sebesar 0,822 atau $82,2 \%$ yang artinya bahwa pada masing-masing variabel yaitu variabel atribut produk, mencari variasi, dan harga dapat menerangkan variabel perpindahan merek. Kemudian diperoleh pula hasil nilai koefesien Analisis Jalur dimana didalamya terdapat hasil uji t beserta nilai original sample dan nilai signifikansi.

Tabel 4. Hasil Nilai Koefesien Analisis Jalur

\begin{tabular}{lccc}
\hline & $\begin{array}{c}\text { Original Sample } \\
(\mathrm{O})\end{array}$ & $\begin{array}{c}\text { T Statistics } \\
(|\mathrm{O} / \mathrm{STDEV}|\end{array}$ & P Values \\
\hline Atribut Produk -> Perpindahan Merek & 0,494 & 3,263 & 0,001 \\
\hline Mencari Variasi -> Perpindahan Merek & 0,104 & 0,431 & 0,667 \\
\hline Harga -> Perpindahan Merek & 0,384 & 2,009 & 0,045 \\
\hline Sumber
\end{tabular}

Sumber: Hasil Output SmartPLS 3.2.7

Berdasarkan tabel 4 di atas dapat dilihat bahwa hasil pengujian variabel atribut produk terhadap perpindahan merek memiliki nilai original sample sebesar 0,494. Selanjutnya, dari hasil pengolahan data uji t-statistik menunjukkan nilai thitung 3,263>ttabel 1,994 (thitung lebih besar dari $t_{\text {tabel}}$ ) dengan nilai siginifikan sebesar 0,001 <0,05 (lebih kecil dari 0,05) . Dengan demikian dapat diartikan bahwa hipotesis diterima $\left(\mathrm{H}_{1}\right.$ diterima $)$ dikarenakan nilai signifikansi 0,001 yaitu lebih kecil dari 0,05. Adapun, variabel atribut produk diartikan berpengaruh terhadap perpindahan merek karena nilai thitung lebih besar dari tabel dengan besar pengaruh $49,4 \%$.

Hasil penelitian ini diperoleh pada konsumen smartphone Oppo di wilayah Ciganjur, Jagakarsa yang mayoritas kosumen berkelamin perempuan dengan rentang usia 16-25 tahun, dengan berpengahasilan $\leq \mathrm{Rp} 3.000 .000$ dan bekerja sebagai pelajar/ mahasiswa. Hasil tersebut didukung pula oleh indeks jawaban responden yang tinggi terhadap atribut produk itu sendiri, sehingga dapat diartikan bahwa manfaat dari smartphone Oppo menarik, inovatif, mudah digunakan, tangguh, aman, dan biaya reparasinya terjangkau.

Hasil penelitian ini sejalan dengan penelitian Wibowo, dkk (2016) yang menyatakan bahwa variabel atribut produk berpengaruh secara signifikan terhadap perpindahan merek walaupun memiliki perbedaan dalam subjek penelitian. Hasil penelitian ini sejalan pula dengan penelitian Ramadhan \& Suhermin (2016) yang menyatakan bahwa pada variabel atribut produk berpengaruh signifikan dan positif terhadap perpindahan merek. Sehingga dapat disimpulkan bahwa semakin baik atribut produk smartphone Oppo, maka akan semakin meningkatkan perpindahan merek dari smartphone lain ke smartphone Oppo.

Masih berdasarkan tabel 4 di atas, dapat dilihat bahwa hasil pengujian variabel mencari variasi terhadap perpindahan merek memiliki nilai original sample sebesar 0,104. Selanjutnya, dari pengolahan data uji t-statistik menunjukkan nilai $t_{\text {hitung }} 0,431<t_{\text {tabel }} 1,994$ ( $\mathrm{t}_{\text {hitung }}$ lebih kecil dari $\mathrm{t}_{\text {tabel }}$ ) dengan nilai signifikan yaitu sebesar 0,667 > 0,05 (lebih besar dari 0,05). Dengan demikian diartikan bahwa hipotesis ditolak $\left(\mathrm{H}_{2}\right.$ ditolak) dikarenakan nilai 
signifikansi 0,667 yaitu lebih besar dari 0,05. Adapun, variabel mencari variasi diartikan tidak berpengaruh terhadap perpindahan merek karena nilai thitung lebih kecil dari $t_{\text {tabel }}$ dengan besar tidak pengaruh $10,4 \%$.

Namun hasil tersebut tidak sejalan dengan indeks jawaban responden yang menyatakan bahwa mencari variasi memiliki indeks yang tinggi, demikian pula perpindahan merek yang memiliki indeks yang tinggi pula. Lebih lanjut, dari hasil analisa deskripstif diketahui pula bahwa konsumen smartphone Oppo di wilayah Ciganjur, Jagakarsa mayoritas berjenis kelamin perempuan dengan rentang usia 16-25 tahun dan sebagian besar memiliki pekerjaan pelajar/mahasiswa.

Tidak berpengaruhnya variabel mencari varisi terhadap perpindahan merek diasumsikan adalah karena mayoritas responden yang berjenis kelamin perempuan. Hal tersebut didukung oleh penelitian Indarwati \& Untarini (2017) yang menyatakan mayoritas responden berjenis kelamin laki-laki tersebut merupakan faktor yang menyebabkan variabel mencari variasi berpengaruh positif dan signifikan terhadap perpindahan merek pada produk smartphone, karena laki-laki cenderung lebih ingin tahu akan kecanggihan teknologi dibandingkan perempuan. Dengan kata lain mayoritas responden yang berjenis kelamin perempuan merupakan salah satu dasar mengapa variabel mencari variasi tidak berpengaruh terhadap perpindahan merek smartphone lain ke smartphone Oppo.

Hasil penelitian ini, yang menyatakan bahwa variabel mencari variasi tidak berpengaruh terhadap perpindahan merek didukung pula oleh Yuliyanto, dkk (2015) yang menyatakan bahwa variabel rasa bosan terhadap produk yang dipakai dan rasa ingin tahu terhadap produk lain pada variety seeking sama-sama tidak memiliki pengaruh yang signifikan terhadap brand switching smartphone ke merek lain berbasis android. Sehingga dapat disimpulkan bahwa seberapa banyak pun variasi di smartphone lain di wilayah Ciganjur, Jagakarsa tidak akan berpengaruh terhadap perpindahan merek smartphone lain ke smartphone Oppo di wilayah Ciganjur, Jagakarsa.

Selanjutnya terkait pengujian variabel harga terhadap perpindahan merek, berdasarkan tabel 4 di atas dapat dilihat bahwa hasil pengujian variabel harga terhadap perpindahan merek memiliki nilai original sample sebesar 0,384. Selanjutnya, dari hasil pengolahan data uji tstatistik menunjukkan nilai $t_{\text {hitung }} 2,009>\mathrm{t}_{\text {tabel }} 1,994$ ( $\mathrm{t}_{\text {hitung }}$ lebih besar dari $\mathrm{t}_{\text {tabel}}$ ) dengan nilai siginifikan yaitu sebesar 0,045 $<0,05$ (lebih kecil dari 0,05). Dengan demikian dapat diartikan bahwa hipotesis diterima $\left(\mathrm{H}_{3}\right.$ diterima) dikarenakan nilai signifikansi 0,045 yaitu lebih kecil dari 0,05. Adapun variabel harga berpengaruh terhadap perpindahan merek karena nilai $t_{\text {hitung }}$ lebih besar dari $t_{\text {tabel }}$ dengan besar pengaruh $38,4 \%$.

Hasil penelitian ini diperoleh pada konsumen smartphone Oppo di wilayah Ciganjur, Jagakarsa yang mayoritas kosumen berkelamin perempuan dengan rentang usia 16-25 tahun, dengan berpengahasilan $\leq \mathrm{Rp} 3.000 .000$ dan bekerja sebagai pelajar/ mahasiswa. Hasil tersebut didukung pula dengan indeks jawaban responden yang tinggi terhadap harga itu sendiri, sehingga dapat diartikan konsumen smartphone Oppo sangat mempertimbangkan peranan alokasi, peranan informasi serta diskon yang ditawarkan.

Terdapat beberapa penelitian yang menyatakan bahwa variabel harga berpengaruh terhadap variabel perpindahan merek. Penelitian Yuliyanto, dkk (2015) menyatakan bahwa harga berpengaruh signifikan terhadap perpindahan merek. Dimana dijelaskan bahwa perbandingan harga produk dengan produk sejenis dan kesesuaian harga dengan kualitas produk pada harga sama-sama memiliki pengaruh terhadap brand switching merek lain 
berbasis Android. Kemudian, dalam penelitian yang dilakukan oleh Ramadhan \& Suhermin (2016) dinyatakan bahwa variabel harga berpengaruh positif dan signifikan. Pernyataan serupa diberikan oleh Dianti (2016) yang menyatakan bahwa variabel harga berpengaruh positif dan signifikan terhadap perpindahan merek. Sehingga dapat disimpulkan bahwa semakin baik harga, maka akan meningkatkan perpindahan merek dari smartphone lain ke smartphone Oppo.

\section{KESIMPULAN DAN SARAN}

Berdasarkan analisis data dan pembahasan yang telah dilakukan mengenai Analisis Perpindahan Merek Smartphone (Studi Kasus Pengguna Smartphone Oppo di Ciganjur, Jagakarsa), maka didapatkan kesimpulan Variabel aribut produk berpengaruh positif dan signifikan terhadap perpindahan merek smartphone lain ke smartphone Oppo, Variabel mencari variasi tidak berpengaruh dan tidak signifikan terhadap perpindahan merek smartphone lain ke smartphone Oppo. Dan variabel harga berpengaruh positif dan signifikan terhadap perpindahan merek smartphone lain ke smartphone Oppo.

\section{DAFTAR RUJUKAN}

Ariani, (2014). Analisis Faktor-Faktor Yang Mempengaruhi Minat Perpindahan Merek Dengan Reference Group Sebagai Variabel Moderating (Studi Kasus Pada Pengguna Provider Indosat M3 Di Kota Semarang), Jurnal Sains Pemasaran Indonesia, Volume XIII, No.2, hlm. 189-210.

Arianto, A.B. (2013). Pengaruh Atribut Produk, Harga, Kebutuhan Mencari Variasi Dan Ketidakpuasan Konsumen Terhadap Keputusan Perpindahan Merek Dari Samsung Galaxy Series Di Kota Malang, Jurnal Aplikasi Manajemen, Volume II, hlm. 294-305.

Dianti. (2016). Pengaruh Atribut Produk, Harga, Variety Seeking Dan Ketidakpuasan Konsumen Terhadap Keputusan Perpindahan Merek Smartphone Di Mataram, Jurnal Sakareang Mataram, Volume 2, No. 3.

Faustine, M. (2015). The Impact Of Variety Seeking, Social Status, Quality, Advertisement Towards Brand Switching In Smartphone Product (A Case Of Blackberry User That Has Ever Changed Into Another Smartphone Product In Surabaya), iBussManagement, Volume 2, hlm. 142-152.

Fitikasari \& Andryan (2018). Brand Switching Behaviour In The Generation Y: Empirical Studies On Smartphone Users, JMK, Volume 20, No.1, hlm. 28-30.

Ghozali, I. (2016). Aplikasi Analisis Multivariate dengan Program IBM SPSS 23, Semarang: Badan Penerbit Universitas Diponegoro.

Hawkins, D. L \& Mothersbaugh. (2010). Consumer Behavior Building Marketing Strategy, 11th edition, New York: McGraw-Hill/Irwin.

Indarwati \& Untarini (2017). Pengaruh Ketidakpuasan Terhadap Keputusan Perpindahan Merek Dengan Kebutuhan Mencari Variasi Sebagai Variabel Moderasi), Jurnal Ilmu Manajemen, Volume 5, No.1.

Jayawijaya, dkk (2017). Pengaruh Kelompok Acuan (Reference Group), Kebutuhan Mencari Variasi Dan Harga Terhadap Perpindahan Merek (Brand Switching) Blackberry Ke Android (Studi Pada Mahasiswa Fakultas Ilmu Administrasi Angkatan 2012 Dan 2013 Universitas Brawijaya Malang), Jurnal Administrasi Bisnis, Volume 4, No.1.

Lovelock, C. Wirtz, J. \&Mussry J. (2010). Manajemen Pemasaran Jasa Jilid 1 Edisi ketujuh, Jakarta: Erlangga.

Sarjono, H. \& Julianita, W. (2011). Spss vs Lisrel: Sebuah Pengantar Aplikasi Untuk Riset, Jakarta: Salemba Empat.

Sutojo, S. (2009). Manajemen Pemasaran untuk Eksekutif Non Pemasaran,Jakarta:PT Damar Mulia Pustaka

Oentoro, D. (2012). Manajemen Pemasaran Modern, Yogyakarta: LaksBangPRESSindo. Tjiptono, F. (2008). Strategi Pemasaran Edisi III, Yogyakarta: ANDI.

TopBrandAward. (2014). Top Brand Index Smartphone, Diakses 03 September 2018. Dari http://www.topbrand-award.com/top-brand-survey/survey-result/top_brand_index_2015_fase_1 
TopBrandAward. (2015). Top Brand Index Smartphone, Diakses 03 September 2018. Dari http://www.topbrand-award.com/top-brand-survey/survey-result/top_brand_index_2015_fase_1

Top Brand Award. (2016). Top Brand Index Smartphone. Diakses 03 September 2018, Darihttp://www.topbrand-award.com/top-brand-survey/surveyresult/top_brand_index_2016_fase_1

Top Brand Award. (2017). Top Brand Index Smartphone. Diakses 03 September 2018, Dari http://www.topbrand-award.com/top-brand-survey/survey-result/top brand index 2017 fase 1

Ramadhan \& Suhermin (2016). Perpindahan Merek : Atribut Produk, Harga Dan Keterlibatan Konsumen, Jurnal Ilmu dan Riset Manajemen, Volume 5 Nomer 3.

Wibowo, dkk. (2014). Pengaruh Atribut Produk Dan Variety Seeking Terhadap Keputusan Perpindahan Merek Handphone Nokia Ke Smartphone Samsung (Survei Pada Outlet Okeshop Itc Roxy Mas, Jakarta Pusat), Jurnal Riset Manajemen Sains Indonesia, Volume 5 Nomer 1.

Yuliyanto, dkk. (2015). Pengaruh Atribut Produk, Harga Dan Variety Seeking Terhadap Brand Switching Smartphone Blackberry Ke Merek Lain Berbasis Android Pada Mahasiswa Jurusan Manajemen Fakultas Ekonomi Universitas Jember, Artikel Ilmiah Mahasiswa.

Yusuf, O. (2018). 5 Vendor Smartphone Terbesar di Indonesia. Di akses pada 05 April 2018, dari https://tekno.kompas.com/read/2018/04/05/12123227/5-vendor-smartphone-terbesar-diindonesia 